\title{
PROSES DAN MOTIF PERUBAHAN MODE BERJILBAB STANDAR KE SYAR'I PADA PELAJAR MA AL IRSYAD GAJAH
}

\author{
Abdul Choliq \\ Fakultas Dakwah, Uin Walisongo Semarang \\ abdulcholiq@gmail.com
}

\begin{abstract}
$H$

eadscarves are something that is familiar to Muslim women who function as someone's Muslim identity. The change in the standard veil mode to the shari'ah that occurs in Madrasah Aliyah students is a new thing out of the ordinary in the Madrasah. The change in the veil style is feared to trigger a negative response from the public who often perceive as a dangerous Islamic group. This study discusses the process of change using the hijab syar'i on students, the motive behind it and the changing attributes after using the hijab syar'i. The method used in this study is a qualitative method with a phenomenological approach. Data collection is done through interview and observation techniques. The results of this study indicate that the process of change towards the headscarf is done slowly by learning the source of books and the internet without studying the scholars 'who understand the problem of syara' about hijab. Furthermore, there are two motives behind the student's decision to switch to the hijab syar'I, which is first: the motive for (motive because) in the form of: religious motives, psychological motives and defense motives. Second, the goal motive (in-order-to-motive) is: the motive for receiving charity and the motive for improving worship. While aspects that change after students wear the hijab syar'I, namely: first, changes in physical attributes, changes in aspects of psychology and changes in idealism in worship.
\end{abstract}

Keywords: Muslim students, social change, hijab.

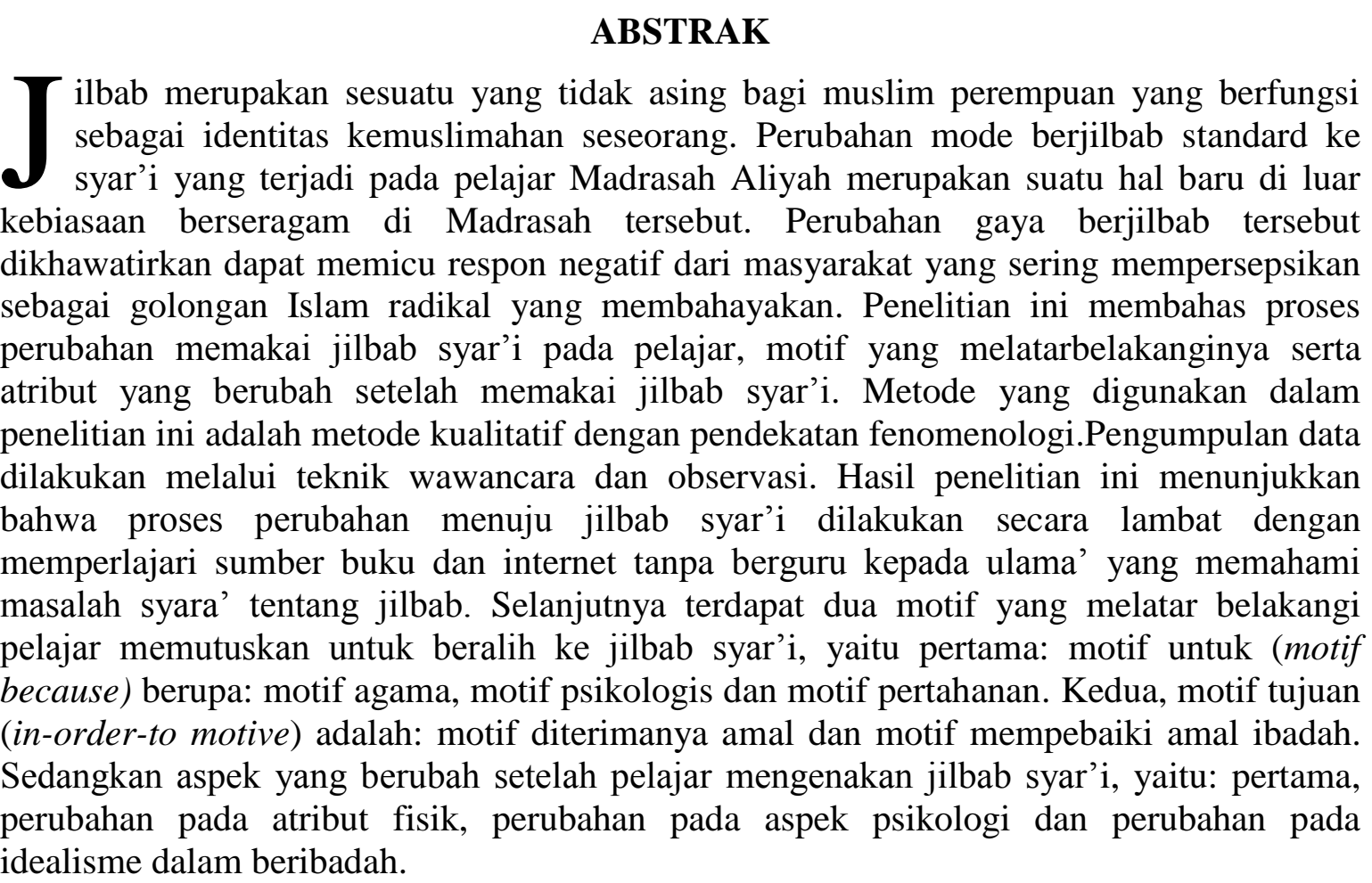

Kata kunci: Pelajarmuslim, perubahan sosial, jilbab.

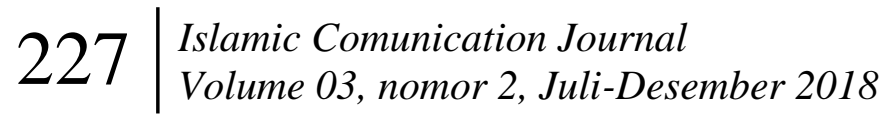




\section{PENDAHULUAN}

Jilbab merupakan sesuatu yang tidak asing bagi kaum muslim perempuan. Jilbab memiliki peranan penting yang berfungsi sebagai identitas kemuslimahan seseorang. Sehingga untuk mengetahui muslim dan tidaknya seseorang salah satunya dapat diukur melalui jilbab yang dikenakan. Jilbab memiliki beberapa ragam jenis, mulai dari jilbab modishingga jilbab syar'i yang identik memiliki ukuran lebih besar daripada jenis lainnya. Perbedaan jenis jilbab yang dipakai perempuan muslim akan menghadirkan penilaian berbeda terhadap si pemakainya. Pemakaian jilbab yang tidak umum di kalangan masyarakat biasanya akanmenuai kontroversi.

Pemakaian hijab tidak mengenal batasan umur, sehingga dari usia balita sampai dewasa akhir tidak ada larangan tentang pemakaian jilbab. Justru di era milenial saat ini telah hadir beragam tutorial pemakaian jilbab dari yang sederhana sampai yang rumit. Saat masih kecil dan usia sekolah dasar, pemakaian jilbab pada anak tergantung bagaimana selera orangtua. Akan tetapi pada usia remaja (pelajar), anak akan cenderung mengikuti trend mode yang berkembang saat itu. Idealnya seorang remaja akan berpenampilan menarik untuk sekedar mencari perhatian dari lawan jenis. Karena mengingat tugas perkembangan pada masa remaja salah satunya adalah munculnya ketertarikan kepada lawan jenis yang biasanya ditandai dengan mencoba - coba hal yang baru (Mappiare, 1982).

Namun dalam kenyataannya terdapat beberapa pelajar di MA Al Irsyad Gajah yang justru melakukan modifikasi dalam berjilbab ketika berada di lingkungan madrasah yang jauh dari kata menarik. Mereka menghadirkan cara berjilbab yang tidak sama dengan pelajarpada umumnya. Yaitu dengan memakai jilbabdengan ukuran besar yang menjuntai ke seluruh tubuh.Mereka juga selalu memakai pakaian yang lebih longgar disertai deker tangan. Tidak jarang mereka mengenakan celana trining di bagian dalam dan rok di bagian luar. Hal tersebut tentunya berlebihan dalam berpakaian dan kurang indah dilihat, seyogyanya perempuan yang suka dengan keindahan.

Fenomena perubahan model pemakaian jilbab dengan ukuran besar tersebut belum diketahui secara pasti apa penyebabnya. Hal ini dikarenakan sebelumnya mereka berpenampilan sebagaimana siswa biasanya dengan memakai jilbab standard dan seragam yang sesuai aturan madrasah. Dalam hitungan minggu secara perlahan - lahan mereka melakukan perubahan mulai dari tata cara berjilbab sampai berpakaian. Sampai saat ini mereka terlihat begitu berbeda dengan rekan di lingkungan sekolah dan di lingkungan tempat tinggalnya (Observasi informan, 2018).

Fenomena pemakaian jilbab sekolah yang menjuntai ke bawah sampai betis oleh pelajar MA Al Irsyad Gajah dikhawatirkan dapat menimbulkan penafsiran keliru dari pihak luar dan mengundang kecurigaan. Karena secara keagamaan, MA Al Irsyad Gajah mengikuti ajaran paham ahlussunnah wal jama'ah yang merupakan golongan garis tengah yang mengedepankan sikap moderat. Selain itu, sejak berdirinya MA 
Proses Dan Motif Perubahan Mode...hal. 227-236

Al Irsyad Gajah tahun 1982,fenomena pemakaian jilbab syar'i pada pelajar, baru muncul pada tahun 2017 dan berlanjut ke tahun 2018 di tengah kondisi masyarakat Indonesia yang memperdebatkan pemakaian jilbab syar'i yang bukan merupakan budaya masyarakat Indonesia. Kebiasaan bertahun - bertahun yang dilakukan siswa MA Al Irsyad Gajah dalam berjilbab adalah mengenakan jilbab yang tidak terlalu kecil dan tidak terlalu besar. Hal terpenting yang ditekankan adalah aurot tertutup dengan baik. Ketika ada yang memakai jilbab terlalu kecil, guru serta merta akan memberikan teguran kepada siswa tersebut untuk memperbaiki cara berjilbabnya.

Pemakaian jilbab yang hampir menutup seluruh tubuh masih menjadi sesuatu yang tidak lazim di lingkungan masyarakat kita. Sampai saat ini jilbab menjadi bahan perdebatan, diskursus, hingga salah satu tolak ukur keimanan seseorang. Permasalahan jilbab bukan hal baru di negara kita, akan tetapi akhir akhir ini persoalan tentang jilbab kembali mencuat. Terlebih banyaknya kasus kasus yang berbau radikal seperti terorisme yang beberapa bulan lalu telah mengancam keselamatan umat di Surabaya. Dimana para pelaku pengeboman mengenakan atribut jilbab yang besar (syar'i).

Fenomena pemakain jilbab syar'i bagi pelajar tersebut kemudian menjadi suatu fenomena dan perubahan sosial yang tidak dapat diabaikan begitu saja meskipun termasuk perubahan social kecil. Oleh karenanya perlu dilakukan kajian lebih jauh dan menjadi suatu penelitian yang menarik. Penelitian ini bertujuan untuk mengetahui bagaimana proses perubahan memakai jilbab syar'I pada pelajar, motif yang melatarbelakanginya serta atribut yang berubah setelah memakai jilbab syar'i.

\section{KAJIAN PUSTAKA}

\section{Konsep Tentang Perubahan dan Evolusi Sosial}

Dalam memahai konsep perubahan social, terdapat beberapa pendapat yang disampaikan oleh beberapa tokoh. Misalnya, Selo Sumarjan menyatakan bahwa perubahan sosial adalah perubahan pada lembaga - lembaga masyarakat yang memngaruhi sistem sosialnya, termasuk nilai - nilai, sikap dan perilaku diantara kelompok - kelompok dalam masyarakat (Maryati dan Suryawati, 2013). Perubahan yang terjadi di masyarakat dapat berupa kemajuan ataupun kemunduran. Oleh sebab itu dalam merespon perubahan diperlukan kearifan dan pemahaman yang mendalam mengenai nilai,arah dan strategi yang sesuai dengan tujuan perubahan itu sendiri. Perubahan sosial merupakan bagian dari perubahan budaya. Dampak perubahan sering dihadapakan pada sistem nilai,norma dan sejumlah gagasan yang difasilitasi banyaknya media sosialsehingga dapat merubah sistem sosial politik,ekonomi,pendidikan maupun sistem budaya setempat.

Berikut ini faktor yang dapat mempengaruhi terjadinya perubahan dalam masyarakat, yaitu: rasa tidak puas terhadap situasi yang ada, timbulnya keinginan untuk mengadakan perbaikan, sikap terbuka terhadap hal - hal yang baru baik datang dari dalam maupun luar masyarakat (Maryati dan Suryawati, 2013). 
Teori yang digunakan untuk memahami proses perubahan pada pelajar yang memutuskan diri untuk mengenakan jilbab syar'I adalah teori evolusi, yaitu sebuah teori yang berpandangan bahwa masyarakat secara bertahap berkembang dari primitivf tradisional menuju masyarakat modern yang kompleks dan maju. Pandangan evolusi tersebut dianut oleh para tokoh dunia pada saat itu. Konsepp evolusi yang sesuai untuk membahas fenomena peralihan jilbab syar'I ke standar lebih tepat menggunakan teori Emile Durkheim yang menyatakan bahwa masyarakat berkembang dari solidaritas mekanik menuju solidaritas organik (Maryati dan Suryawati, 2013).

\section{Konsep Motivasi Scutz}

Menurut KBBI (2002), motivasi adalah dorongan yang timbul pada diri seseorang secara sadar atau tidak sadar untuk melakukan tindakan dengan tujuan tertentu. Dalam ilmu psikologi disebutkan bahwa motivasi adalah usaha yang menyebabkann seseorang atau kelompok orang tertentu tergerak melakukan sesuatu karena ingin mencapai tujuan yang dikehendakinya atau mendapatkan kepuasan dengan perbuatannya.

Untuk menggambarkan keseluruhan tindakan seseorang Schutz mengelompokan dalam 2 fase, yaitu: (1) Because-motives yaitu tindakan yang merujuk pada masa yang sudah terlewati. Dimana, tindakan yang akan dilakukan oleh seseorang pasti memiliki alasan dari masa lalu ketika ia melakukannya dan (2) In-order-to-motive yaitu motif yang merujuk pada tindakan di masa mendatang. Dimana, tindakan yang dilakukan oleh sesorang pasti memiliki tujuan yang telah di tetapkan (Kuswarno, 2009).

\section{Jilbab}

Secara etimologis jilbab berasal dari bahasa Arab jalaba yang berarti menghimpun atau membawa. Istilah jilbab digunakan pada negara-negara yang berpenduduk muslim lain sebagai jenis pakaian dengan penamaan yang berbeda. Misalnya, di Iran disebut chandor, di India dan Pakistan disebut pardeh, penduduk Libya menyebutnya milayat, penduduk Irak menamakan Abaya, di Malaysia disebut tudung dan di daerah Arab-Afrika dinamakan hijab. Nuvida Raf dalam Hardiyanti (2012) lebih menekankan jilbab pada kata hijab yang berarti penutup, pembungkus, tirai atau partisi.

Al-Biqa'i (dalam Thohari, 2011) yang menyebutkan beberapa arti dari kata jilbab yaitu baju yang longgar atau kerudung penutup kepala wanita, atau pakaian yang menutupi baju dan kerudung yang dipakainya, atau semua pakaian yang menutupi badan wanita. Berdasarkan pengertian itu maka dapat dikatakan bahwa yang dimaksud dengan jilbab adalah baju, maka jilbab adalah pakaian yang menutupi tangan dan kakinya. Sedangkan jika disebut kerudung maka terdapat perintah untuk mengulurkannya, yaitu menutup wajah dan lehernya. Selanjutnya jika maknanya pakaian yang menutupi badan maka perintah mengulurkannya adalah membuatnya longgar sehingga menutupi semua badan dan pakaian.

Menurut Kamus Besar Bahasa Indonesia, jilbab diartikan sebagai kerudung lebar yang dipakai muslimah

Islamic Comunication Journal Volume 3, Nomor 2, Juli-Desember 2018 
Proses Dan Motif Perubahan Mode...hal. 227-236

untuk menutupi kepala dan leher hingga dada (KBBI, 2002). Jilbab versi Indonesia pada awalnya lebih dikenal dengan sebutan kerudung atau mikromah yaitu kain untuk menutupi kepala, tetapi masih memperlihatkan bagian leher dan sebagian rambut. Bentuknya ada yang seperti sarung atau segi empat biasa yang ukuran jilbabnya tidak terlalu besar. Selain itu, gaya pemakaian jilbab segi 4 hanya ditalikan kedepan dan jilbab bagian telinga diletakkan di belakang daun telinga untuk menahan supaya jilbab tidak terjatuh. Baru pada awal tahun 1980an istilah jilbab mulai dikenal, yaitu kerudung yang juga menutup leher dan semua rambut.

Secara fungsi, jilbab memiliki dua dimensi, yaitu materi dan rohani, jilbab materi berupa penutup tubuh. Sedangkan jilbab rohani adalah kondisi yang menjelaskan perempuan di tengah kehidupan masyarakat tidak berusaha tampil dengan dandanan yang menarik perhatian, dalam artian bahwa jilbab rohani ini adalah pencegah dari penyimpangan dan kemerosotan akhlak dan perilaku. Kedua dimensi memiliki keterkaitan dan saling memengaruhi, jilbab materi berfungsi sebagai upaya yang bersifat preventif sehingga jilbab rohani pun akan terjaga dengan terjaganya jilbab materi (Fadlulloh, 2000).

Di Indonesia, kata jilbab merujuk pada corak pakaian Islam tertentu, namun seringkali maknanya tidak konsisten. Ada yang memahami jilbab sebagai penutup kepala, ada juga yang memaknainya sebagai pakaian komplit. Terlepas dari perbedaan dalam memahami makna jilbab tersebut, jilbab atau hijab berorientasi makna sebagai pakaian perempuan muslimah terkait dengan agama Islam.

\section{Pelajar Bagian dari UsiaRemaja}

Pelajar atau peserta didik adalah anggota masyarakat yang berusaha mengembangkan potensi diri melalui proses pembelajaran yang tersedia pada jalur, jenjang, dan jenis pendidikan tertentu. Setiap peserta didik berkewajiban menjaga norma-norma pendidikan untuk menjamin keberlangsungan proses dan keberhasilan pendidikan (UU Sisdiknas, 2003).Kemudian aturan UU Sisdiknas tersebut dijelaskan dalam PP No 17 Tahun 2010 tentang Pengelolaan dan Penyelenggaraan Pendidikan yang salah satunya menjelaskan tentang kewajiban peserta didik, yaitu:

a. mengikuti proses pembelajaran sesuai peraturan satuan pendidikan dengan menjunjung tinggi norma dan etika akademik;

b. menjalankan ibadah sesuai dengan agama yang dianutnya dan menghormati pelaksanaan ibadah peserta didik lain;

c. menghormati pendidik dan tenaga kependidikan;

d. memelihara kerukunan dan kedamaian untuk mewujudkan harmoni sosial;

e. mencintai keluarga, masyarakat, bangsa, dan negara, serta menyayangi sesama peserta didik;

f. mencintai dan melestarikan lingkungan;

g. ikut menjaga dan memelihara sarana dan prasarana, kebersihan, keamanan, dan ketertiban satuan pendidikan; 
Abdul Choliq

h. ikut menjaga dan memelihara sarana dan prasarana, kebersihan, keamanan, dan ketertiban umum;

i. menanggung biaya pengelolaan dan penyelenggaraan pendidikan, kecuali yang dibebaskan dari kewajiban;

j. menjaga kewibawaan dan nama baik satuan pendidikan yang bersangkutan; danmematuhi semua peraturan yang berlaku.

Ketentuan lebih lanjut mengenai kewajiban peserta didik sebagaimana di atas diatur oleh satuan pendidikan yang bersangkutan (PP No 17 Tahun 2010).

Secara perkembangan, usia pelajar Madrasah Aliyah berada di rentang tahap usia perkembangan remaja yaitu antara usia $12-18$ tahun Usia remaja merupakan usia terjadinya proses penyempurnaan pertumbuhan fisik, psikologis dan sosial yang mengarah pada kematangan individu (Mappiare, 1982). Aspek-aspek tersebut terus berkembang hingga masa dewasa awal (Erickson dalam Booree, 2010).. Berikut ini merupakan karakteristik-karakteristik yang ditemui pada masa remaja:

1. Ketidakstabilan perasaan dan emosi

2. Munculnya perilaku yang berkaitan dengan moral

3. Meningkatnya argumentasi yang masuk akal

4. Munculnya masalah yang berkaitan dengan emosionalitas

5. Masa yang kritis

\section{METODE PENELITIAN}

Metode yang digunakan dalam penelitian ini adalah metode penelitian kualitatif dengan pendekatan fenomenologi dikarenakan keinginan peneliti untuk memahami sebuah fenomena yang terjadi secara lebih mendalam. Sementara dalam menentukan responden peneliti menggunakan purposive sampling atau memilih responden berdasarkan kriteria yang sudah ditentukan. Adapun kriterianya adalah:

1) Responden adalah pelajar perempuan usia 15 - 17 tahun

2) Responden adalah pelajar yang mengalami perubahan gaya berjilbab dari jilbab standar ke jilbab syar'i di lingkungan MA Al Irsyad Gajah.

\section{HASIL PENELITIAN DAN PEMBAHASAN}

Penelitian ini dilaksanakan mulai bulan Februari- September 2018. Data diambil melalui wawancara dan observasi kepada responden. Jumlah responden dalam penelitian ini sebanyak 3 pelajar yakni Sulistiani, Salma Rosidatul Muna dan Neha Risma Fauzia yang ketiganya merupakan siswa kelas XI IBB.

\section{Proses pemakaian jilbab syar'I pada pelajar MA Al Irsyad Gajah}

Perubahan mode pakaian termasuk di dalamnya gaya berjilbab merupakan bagian dari perubahan sosial kecil. Suatu perubahan dianggap kecil jika perubahan itu terjadi pada unsur - unsur struktur sosial yang tidak membawa pengaruh langsung bagi masyarakat (Moore dalam Soekanto, 1982). Begitupun juga yang terjadi pada informan bahwa proses peralihannya menuju gaya berjilbab syar'I merupakan perubahan kecil yang kurang berpengaruh terhadap lingkungan sosialnya. Meskipun demikian, perubahan gaya berjilbab ini yang pada awalnya 
Proses Dan Motif Perubahan Mode...hal. 227-236

terjadi pada satu pelajar, kini bertambah menjadi dua. Jadi total pelajar dengan gaya berjilbab syar'i atau jilbab syar'i sebanyak tiga pelajar.

Proses transisi menuju gaya berjilbabb syar'I pada informan diawali dari penilaian yang berasal dari teman informan bahwa jilbab yang dipakai cenderung tipis. Setalah itu informan mencari informasi yang berkaitan dengan cara berjilbab yang sesuai dengan syariat agama. Terdapat dua media yang dijadikan sumber belajar tentang cara berjilbab yang baik. Pertama melalui buku bacaan yang terdapat di perpustakaan dimana ia sekolah, kedua melalui browsing di internet tentang anjuran syara' tentang berjilbab dan melalui pengajian - pengajian yang ada di youtube.

Perubahan gaya berjilbab pada informan mendapat kritikan khususnya yang berasal dari keluarga informan. Hal tersebut dikarenakan anggota keluarga mereka tidak ada yang mengenakan jilbab dengan ukuran besar. Akan tetapi perlahan-lahan keluarga dapat menerima kondisi informan tersebut. Bagi informan, kritikan tersebut justru dijadikan cambuk untuk membuktikan diri bahwa dengan berjilbab syar'i ia mampu menjaga dirinya dari perbuatan yang keji.

\section{Motif pemakaian jilbab syar'i pada pelajar MA Al Irsyad Gajah}

Motif merupakan sebuah dorongan yang berasal dari dalam individu untuk melakukan sesuatu. Hal ini senada yang dinyatakan Purwanto (2008) bahwa motif merupakan suatu dorongan yang timbul dalam diri seseorang yang menyebabkan seseorang mau bertindak melakukan sesuatu. Adanya motif pada diri seseorang menunjukkan adanya keinginan kuat untukk mencapai tujuan, harapan dan target - target yang telah direncanakan seseorang.

Dalam pemakaian jilbab syar'i, ketiga informan tersebut selalu mengenakannya setiap kali keluar rumah, baik ketika datang ke madrasah maupun ketika bepergian. Mereka berpendapat, dengan memakai jilbab syar'i mereka merasa nyaman dan tenang, tidak khawatir akan diganggu orang lain terutama kaum Adam.

Sebenarnya madrasah sudah menerapkan aturan yang jelas tentang pemakaian jilbab bagi pelajar putri, yakni cukup sampai menutup dada. Jadi tidak boleh dimodifikasi. Peraturan itu sudah berjalan bertahun-tahun.

Dalam penelitian ini, pelajar melakukan transisi mode berjilbab yang awalnya memakai jilbab selayaknya siswa yang lain (sesuai aturan madarasah) menjadi hijab syar'i tentunya disebabkan oleh beberapa alasan. Menurut Schutz, hal yang ditekankan dalam perubahan cara berjilbab pelajar dipandang sebagai suatu tindakan sosial berbasis histori atau sejarah. Dalam menggambarkan tindakan atau perilaku seseorang, Schutz menyimpulkann bahwa munculnya periaku seseorang dipengaruhi oleh perilaku diri sendiri ataupun orang lain baik di masa lalu, masa sekarang ataupun masa mendatang. Oleh karena itu, Schutz mengelompokkan motif seseorang ke dalam dua jenis, yaitu because motive (motif karena) dan in-order-to-motive (motif untuk) (Kuswarno, 2009).Because motif berorientasi pada tindakan yang 
Abdul Choliq

akandilakukan oleh seseorang pasti memiliki alasan dari masa lalu. Sementara in-order-to-motiveberorientasi pada tindakan yang dilakukan oleh seseorang pasti memiliki tujuan yang akan dicapai.

Berdasarkan data yang diperoleh, yang menjadi motif masa lalu (because motif) pada pelajar untuk beralih ke mode berjilbab syar'i adalah: Pertama, motif agama, yaitu dorongan yang muncul dalam rangka menjalankan perintah Allah dan ingin menjadi seorang muslimah yang sebenarnya dengan menutup anggota tubuhnya sesuai syariat. Karena sebelumnya informan masih suka pakailepas jilbab.Kedua, motif psikologis berupa kenyamanan. Hal tersebut disebabkan karena sebelum memakai jilbab syar'I, pelajar merasa tidak percaya diri dengan jilbab standar sebagaimana yang dipakai pelajar lain; Ketiga,motif pertahanan untuk mencegah diri supaya terhindar dari perilaku tidak terpuji dan gangguan dari orang lain. Motif ketiga ini sesuai dengan yang tersirat dalam Q.S. Al Ahzab: 59 yang memiliki kandungan makna bahwa "dengan mengulurkan jilbab ke seluruh tubuh, mereka akan mudah dikenal dan mereka tidak diganggu". Pada dasarnya motive because erat kaitannya dengan alasan - alasan yang menjadikan informan memutuskan untuk memakai jilbab syar'i.

Sementara yang menjadi tujuan dari in-order-to-motivepada informan digambarkan melalui rencana dan harapan yang ingin dicapai. Terdapat tujuan tersendiri bagi pelajar ketika meyakinkan dirinya untuk beralih memakai jilbab syar'I, yaitu: Pertama, motif diterimanya amal ibadah. Hal ini didasarkan pada pemahaman informan tentang pentingnya menutup aurot dalam sebuah buku yang dibacanya "tidak akan diterima amal ibadah seseorang bagi yang tidak menutup auratnya".Kedua, motif untuk memperbaiki amal ibadah dari segi kualitas maupun kuantitas.

\section{Aspek yang Berubah Setelah Setelah Pelajar Beralih Memakai Jilbab Syar'i}

Perubahan yang terjadi pada seseorang memiliki dua arah, yaitu perubahan ke arah positif dan negatif (Sukanto, 1982).Perubahan yang terjadi pada informan tidak langsung sekali jadi, akan tetapi berjalan dari waktu ke waktu hingga tahun kedua mengenakan jilbab syar'i. Beberapa perubahan yang terjadi pada pelajarsetelah beralih memakai jilbab syar'I, antara lain: pertama, perubahan terhadap atribut fisik yang dikenakannya seperti perubahan cara memakai seragam dimana saat ini informan menambah kaos deker yanga panjang sampai lengan tangan bahkan jari - jari, memakai celana panjang untuk dalaman rok, memakai celak di bagian bawah mata yang begitu tebal serta terkadang memakai cadar ketika bepergian; kedua, perubahan pada aspek psikologis dimana pelajar memiliki rasa percaya diri dan keberanian yang lebih dibandingkan sebelum memakai jilbab syar'i.Tentunya hal tersebut menjadii identitas dan konsep diri baru bagi pelajar tersebut; ketiga, perubahan pada idealisme dalam beribadah dimana ada upaya - upaya yang dilakukan pelajar untuk bisa meningkatkan amal ibadah dalam bentuk ibadah sunnah. Beberapa perubahan tersebut menunjukkan arah perubahan yang positif karena berkaitan 
Proses Dan Motif Perubahan Mode...hal. 227-236

dengan hal - hal yang lebih baik daripada sebelumnya (Sukanto, 1982).

Berkaitan dengan perubahan yang terjadi pada informan, terdapat temuan baru bahwa meskipun arah perubahan mengarah pada hal positif, akan tetapi jika dilakukan tanpa mempertimbangkan aspek kemaslahatan lingkungan sekitarnya, perubahan yang awalnya positif bisa berubah wajah menjadi hal yang negatif. Seperti yang dilakukan salah seorang informan bahwa tujuan mulianya meningkatkan ibadah sunnah berupa sholat dzuha, akan tetapi ia mengabaikan tugas piket kebersihan kelas.Selain melanggar kewajiban sebagai anggota kelas, ia juga melanggar hak siswa lain untuk mendapatkan lingkungan kelas yang bersih. Artinya, sebagai warga negara Indonesia kita memiliki 2 identitas sekaligus yaitu identitas pribadi dan identitas kelompok. Selalu ada kepentingan yang melekat pada setiap identitas, akan tetapi identitas kelompok harus didahulukan daripada identitas pribadi. Karena secara sadar atau tidak, kita hidup dinegara pancasila yang harus menjunjung tinggi nilai - nilai pancasila khususnya sila ketiga untuk tetap menegakkan persatuan di negeri yang multikultural ini.

Selain itu, informan cenderung lebih kaku (galak) dalam merespon situasi yang terjadi di luar harapannya. Seharusnya informan harus lebih bisa menahan amarahnya ketika menjumpai kejadian yang tidak disukainya. Oleh sebab itu, terdapat poin penting yang harus diperhatikan bagi siapapun khususnya yang mengenakan jilbab syar'i, karena jilbab merupakan representasi dari keseluruhan pribadi seseorang. Sehingga seseorang harus menyeimbangkan antara kehidupan dunia dan akhirat dan tidak memenangkan salah satu diantara keduanya, karena islam adalah agama yang rahmatalli'alamiin, toleran dan cinta damai. Karenanyaperlu diketahui bahwa tingkat kesalehan seseorang tidak diukur melalui seberapa besar jilbabnya, karena jilbab hanyalah sebuah simbol yang lahir dari konstruksi sosial (Yulikhah, 2016).Oleh sebab itu, guna menyelaraskan pemahaman tentang pemakaian jilbab, sebaiknya seseorang harus mempelajari secara keseluruhan tentang jilbab dengan belajar kepada guru yang tepat(Q.S. An Nahl: 43). Sehingga perubahan positif yang terjadi pada informan juga berdampak positif bagi diri dan lingkunganya.

\section{KESIMPULAN}

Berdasarkan pada penjelasan sebelumnya, dapat dibuat tiga kesimpulan, yaitu:

1. Proses perubahan menuju jilbab syar'i dilakukan secara lambat dengan mempelajari buku yang membahas tentang jilbab yang dipinjamnya dari perpustakaan dan melihat/mendengarkan tausiyah tausiyah melalui youtube, tanpa berguru atau konfirmasi kepada ulama' yang memahami masalah syara' tentang jilbab.

2. Terdapat dua motif yang melatar belakangi pelajar memutuskan untuk beralih ke jilbab syar'i, yaitu pertama: motif untuk (motif because) berupa: motif agama, motif psikologis dan motif pertahanan. Kedua, motif tujuan (in-order-to motive) adalah: motif 
Abdul Choliq

diterimanya amal dan motif mempebaiki amal ibadah.

3. Terdapat 3 aspek yang berubah setelah pelajar mengenakan jilbab syar'I, yaitu: pertama, perubahan pada atribut fisik, perubahan pada aspek psikologi dan perubahan pada idealisme dalam beribadah.

\section{DAFTAR PUSTAKA}

\section{Al Qur'an Al Karim}

Boeree, G. 2010. Personality Theories. Jakarta: Prismasophie.

Fadhlullah, Sayid Muhammad Husain. 2000. Dunia Wanita dalam Islam. Jakarta: Lentera.

Kuswarno, Enkus. 2009. Metodologi Penelitian Komunikasi Fenomenologi: Konsepsi, Pedoman, Dan Contoh Penelitian Fenomena Pengemis Kota Bandung. Bandung:Widya Padjadjaran

Mappiare, A. (1982). Psikologi Remaja. Surabaya: Usaha Nasional.

Maryati dan Suryawati. 2014. Sosiologi: Kelompok Peminatan Ilmu - Ilmu Sosial. Jakarta: Erlangga

Peraturan Pemerintah No 17 Tahun 2010 tentang Pengelolaan dan Penyelenggaraan Pendidikan.

Pusat Bahasa Departemen Pendidikan Nasional. 2002. KBBI Edisi Ketiga. Jakarta: Balai Pustaka
Soekanto, Soerjono. 1982. Sosiologi Suatu Pengantar. Jakarta: PT Raja Grafindo Persada.

Thohari, Chamim. 2011. Konstruksi Pemikiran Quraish Shihab tentang Hukum Jilbab: Kajian Hermeneutika Kritis. Malang: Jurnal Volume 14 Nomor 1 Januari - Juni 2011, Universitas Negeri Malang.

Undang - Undang No 20 Tahun 2003 Tentang Pendidikan Nasional

Yulikhah. 2016. Jilbab: Antara Kesalehan dan Fenomena Sosial. Jurnal: JURNAL ILMU DAKWAH, Vol. 36, No.1, Januari - Juni. 